\title{
PASAL IMUNITAS UNDANG-UNDANG 'CORONA' DAN KEWENANGAN BADAN PEMERIKSA KEUANGAN DALAM MENETAPKAN KERUGIAN NEGARA
}

\author{
Kusnadi Umar \\ Universitas Islam Negeri Alauddin Makassar \\ kusnadi.umar@uin-alauddin.ac.id
}

\begin{abstract}
Article 27 paragraph (1) of Law No. 2 of 2020 (Corona Law) in particular the phrase "is not a state financial loss", is regarded as an article of immunity and its existence is deemed to be able to enforce the authority of the BPK as an authoritative state institution in assessing or establishing a financial loss of state. Provisions governing the authority of the BPK and the financial losses of the State, not including part of the provisions which are expressly revoked and/or otherwise void in the provisions of Article 28 of the Corona Law, which specifically contains and confirms the invalidity of the clauses of the various laws. While the phrase "is not a state financial loss" can not be justifying, because the formulation is still common, it tends to potentially cause disharmony between regulations. So in a juridical, the existence of Article 27 paragraph (1) of Corona Law, cannot enforce the authority of the BPK in assessing or establishing financial losses of state.
\end{abstract}

Keywords: Corona law; BPK; State losses; Covid-19

\begin{abstract}
Abstrak
Pasal 27 Ayat (1) Undang-undang Nomor 2 Tahun 2020 (Undang-undang Corona) khususnya frasa "bukan merupakan kerugian negara", diperspektifkan sebagai pasal imunitas dan keberadaannya dianggap dapat menegasikan kewenangan BPK sebagai lembaga Negara yang otoritatif dalam menilai atau menetapkan kerugian Negara. Ketentuan-ketentuan yang mengatur mengenai kewenangan BPK maupun kerugian Negara, tidak termasuk bagian dari ketentuan-ketentuan yang secara tegas dicabut dan/atau dinyatakan tidak berlaku dalam ketentuan Pasal 28 Undang-undang Corona, yang secara khusus memuat dan menegaskan ketidakberlakuan pasal-pasal dari pelbagai Undang-undang. Sementara frasa "bukan merupakan kerugian negara" tidak dapat dijadikan justifikasi, karena rumusannya masih bersifat umum, bahkan cenderung berpotensi menimbulkan disharmonisasi antar peraturan perundangan-undangan. Sehingga secara yuridis, keberadaan Pasal 27 Ayat (1) Undang-undang Corona, tidak dapat menegasikan kewenangan BPK dalam menilai atau menetapkan kerugian Negara.
\end{abstract}




\section{Kata Kunci: Undang-Undang, BPK, Kerugian Negara, Covid-19.}

\section{PENDAHULUAN}

Corona Virus Disease 2019 (Covid-19) telah mewabah kepelbagai negara, bahkan telah ditetapkan sebagai pandemi global oleh World Health Organization (WHO). ${ }^{1}$ Di Indonesia, kasus positif pertama diumumkan secara resmi oleh pemerintah pada tanggal 2 Maret 2020, setelah sebelumnya dibantah dan diyakini oleh beberapa menteri bahwa Covid-19 tidak akan masuk ke Indonesia dengan beragam alasan, yang secara ilmiah sulit diterima akal sehat. ${ }^{2}$ Bantahan dan optimisme yang dipertontonkan beberapa menteri, oleh sebagian kalangan dianggap sebagai sikap yang meremehkan dan terkesan kurang serius dalam mengambil langkah-langkah antisipatif terhadap penyebaran Covid-19.

Memasuki minggu ketiga bulan Maret, jumlah kasus positif telah mencapai 1.414. ${ }^{3}$ Trend penyebaran yang terus mengalami peningkatan, serta telah berdampak pada pelbagai aspek, khususnya aspek kesehatan, sosial, dan ekonomi 'memaksa' pemerintah untuk bergerak cepat merumuskan kebijakan dan langkahlangkah penanganan. Salah satu kebijakan (beleid) yang dikeluarkan adalah Peraturan Pemerintah Pengganti Undang-undang (Perppu) Nomor 1 Tahun 2020 tentang Kebijakan Keuangan Negara dan Stabilitas Sistem Keuangan untuk Menangani Pandemi Covid-19 dan/atau dalam Rangka Menghadapi Ancaman yang Membahayakan Perekonomian Nasional dan/atau Stabilitas Sistem Keuangan. ${ }^{4}$

Perppu tersebut, dijadikan payung hukum untuk memperkuat kewenangan lembaga-lembaga negara disektor keuangan, dalam merumuskan dan mengambil

${ }^{1}$ Direktur Jenderal World Health Organization (WHO), Tedros Adhanom Ghebreyesus, secara resmi mengumumkan status Corona Virus Disease 2019 (Covid-19) sebagai Pandemi Global pada tanggal 11 Maret 2020 di Jenewa - Swiss. https://www.kompas.com/tren/read/2020 /03/12/003124065/menyebar-hingga-118-negara-virus-corona-ditetapkan-who-sebagai-pandemi Diakses pada tanggal 20/05/2020.

${ }^{2}$ Hasil riset yang dilakukan oleh Lembaga Penelitian, Pendidikan, Penerangan Ekonomi Sosial (LP3ES) menyimpulkan telah terjadi 37 pernyataan blunder pejabat pemerintahan baik sebelum maupun setelah krisis berlangsung, pernyataan-pernyataan blunder tersebut dilakukan antara lain oleh Wakil Presiden, Menteri Kesehatan, Menko Maritim, Menko Polhukam, Menko Perekonomian, Menteri Perhubungan, Kepala BNPB, Menteri Pariwisata, Juru Bicara Presiden, Juru Bicara Pemerintah untuk Penanganan Covid. Lihat. https://nasional.kompas.com/read/ 2020/04/06/17522121/Ip3es-catat-ada-37-pernyataan-blunder-pemerintah-soal-covid-19 Diakses pada tanggal 20/05/2020.

3 Tirto.id "Update Corona 30 Maret 2020: Data di Indonesia, 31 Provinsi \& Dunia" https://tirto.id/update-corona-30-maret-2020-data-di-indonesia-31-provinsi-dunia-eJJx Diakses tanggal 20/05/2020.

${ }^{4}$ Perppu merupakan salah satu hak konstitusional Presiden yang diatur dalam Pasal 22 Ayat (1) Undang-undang Dasar Negara Republik Indonesia Tahun 1945 (UUD NRI 1945).

115 
kebijakan serta langkah-langkah luar biasa (extra ordinary), dalam rangka penyelamatan perekonomian nasional. Dengan fokus pada peningkatan belanja untuk kesehatan, jaring pengaman sosial (sosial safety net), dan pemulihan perekonomian, melalui realokasi dan refocusing Anggaran Pendapatan dan Belanja Negara (APBN), termasuk Anggaran Pendapatan Belanja Daerah (APBD) bagi Pemerintah Daerah. ${ }^{5}$

Sejak pertama kali diberlakukan, Perppu Corona ${ }^{6}$ telah menuai kontroversi. Ada yang menanggapi secara positif, tetapi tidak sedikit yang mengkritisi, mulai dari politisi, tokoh nasional, akademisi, praktisi, dan penggiat anti korupsi, bahkan beberapa kelompok masyarakat telah mengajukan judicial review ke Mahkamah Konstitusi. ${ }^{7}$ Meskipun, Perppu Corona masih harus memperoleh persetujuan Dewan Perwakilan Rakyat (DPR), tetapi publik sudah bisa membaca dan memprediksi sikap DPR dengan melihat konfigurasi dan peta koalisi partai politik. Akhirnya prediksi tersebut terbukti setelah pada tanggal 16 Mei 2020, DPR $^{8}$ menyetujui Perppu Corona menjadi Undang-undang Nomor 2 Tahun 2020 tentang Penetapan Peraturan Pemerintah Pengganti Undang-undang Nomor 1 Tahun 2020 tentang Kebijakan Keuangan Negara dan Stabilitas Sistem Keuangan untuk Menangani Pandemi Covid-19 dan/atau dalam Rangka Menghadapi Ancaman yang Membahayakan Perekonomian Nasional dan/atau Stabilitas Sistem Keuangan. ${ }^{9}$

Setelah memperoleh persetujuan DPR, pada tanggal 18 Mei 2020, Perppu Corona secara resmi diundangkan dalam lembaran negara. Persetujuan Perppu Corona menjadi Undang-undang Nomor 2 Tahun 2020 (selanjutnya disebut Undang-undang Corona), ternyata tidak menjadikan kontroversi diruang-ruang

${ }^{5}$ Berita Sekretariat Kabinet Republik Indonesia, "Isi Perpu Kebijakan Keuangan Negara dan Stabilitas Sistem Keuangan Negara Hadapi Covid-19". https://setkab.go.id/isi-perpu-kebijakankeuangan-negara-dan-stabilitas-sistem-keuangan-hadapi-covid-19/ Diakses 20/05/2020.

6 Perppu Nomor 1 Tahun 2020 diundangkan pada tanggal 31 Maret 2020, Lembaran Negara Republik Indonesia Tahun 2020 Nomor 87, Tambahan Lembaran Negara Republik Indonesia Nomor 6485.

7 Berita Humas Mahkamah Konstitusi RI, "Sejumlah Masyarakat Gugat Konstitusionalitas Perppu corona". https://mkri.id/index.php?page=web.Berita\&id=16330\&menu=2 Diakses 20/05/2020.

8 Ketentuan Pasal 22 Ayat (2) Undang-undang Dasar Negara Republik Indonesia Tahun 1945 berbunyi "Peraturan pemerintah itu harus mendapat persetujuan Dewan Perwakilan Rakyat dalam persidangan yang berikut". Secara eksplisit, ketentuan tersebut hanya memberikan kewenangan kepada DPR untuk memberikan persetujuan atau tidak memberikan persetujuan terhadap Perppu yang diajukan oleh Presiden. Lihat juga Pasal 52 Ayat (3) Undang-undang Nomor 12 Tahun 2011 tentang Pembentukan Peraturan Perundang-undangan.

${ }^{9}$ Undang-undang Nomor 2 Tahun 2020, Lembaran Negara Republik Indonesia Tahun 2020 Nomor 134, disahkan tanggal 16 Mei 2020, dan diundangkan pada tanggal 18 Mei 2020.

\section{6}


publik otomatis terhenti, dan masih mempersoalkan ketentuan dengan substansi yang sama, yang sebelumnya diatur dalam Perppu Corona, ${ }^{10}$ salah satunya yaitu Pasal 27 Ayat (1) Undang-undang Corona yang lengkapnya berbunyi "Biaya yang telah dikeluarkan Pemerintah dan/atau lembaga anggota KSSK dalam rangka pelaksanaan kebijakan pendapatan negara termasuk kebijakan dibidang perpajakan, kebijakan belanja negara termasuk kebijakan di bidang keuangan daerah, kebijakan pembiayaan, kebijakan stabilitas sistem keuangan, dan program pemulihan ekonomi nasional, merupakan bagian dari biaya ekonomi untuk penyelamatan perekonomian dari krisis dan bukan merupakan kerugian negara"

Frasa "bukan merupakan kerugian negara" dalam rumusan pasal di atas, diperspektifkan sebagai imunitas bagi pemerintah dan $\mathrm{KSSK}^{11}$ untuk menghindari delik korupsi dalam pengelolaan dana penanganan pandemi Covid-19. Pandangan tersebut nampaknya tidak berlebihan, sebab sejarah panjang penanganan bencana, selalu menyisakan aksi-aksi tidak terpuji dari oknum-oknum yang memanfaatkan situasi. Apalagi unsur kerugian Negara, merupakan salah satu unsur yang menentukan apakah suatu peristiwa merupakan tindak pidana korupsi atau bukan, khususnya setelah Mahkamah Konstitusi dalam putusan Nomor 25/PUUXIV/2016, ${ }^{12}$ mengubah delik formil Pasal 2 Ayat (1) dan Ayat (3) Undangundang Pemberantasan Tindak Pidana Korupsi (Undang-undang PTPK) menjadi delik materil.

Kerugian negara merupakan salah satu unsur yang harus ada dalam tindak pidana korupsi, dalam pengertian inti selain perbuatan-perbuatan korupsi lainnya seperti gratifikasi. Unsur kerugian Negara, merupakan unsur pokok selain unsur

10 Pasal 1 Undang-undang Nomor 2 Tahun 2020 menegaskan bahwa Perppu Corona menjadi lampiran yang tidak terpisahkan dari Undang-undang Nomor 2 Tahun 2020.

${ }^{11}$ KSSK adalah Komite Stabilitas Sistem Keuangan yang beranggotakan Menteri Keuangan, Gubernur Bank Indonesia (BI), Ketua Dewan Komisioner Otoritas Jasa Keuangan (OJK), dan Ketua Dewan Komisioner Lembaga Penjamin Simpanan (LPS).

12 Putusan Mahkamah Konstitusi Nomor 25/PUU-XIV/2016, tanggal 25 Januari 2017 yang menyatakan kata "dapat" dalam Pasal 2 ayat (1) dan Pasal 3 Undang-undang PTPK bertentangan dengan UUD NRI 1945 dan tidak mempunyai kekuatan hukum mengikat, dengan pertimbangan bahwa pencantuman kata "dapat" dalam Pasal 2 Ayat (1) dan Pasal 3 Undang-undang PTPK tersebut menimbulkan ketidakpastian hukum dan berpotensi terjadinya penyalahgunaan wewenang oleh penegak hukum. Penerapan unsur merugikan keuangan negara dengan konsepsi actual loss lebih memberikan kepastian hukum yang adil. Lihat. Supriyanto, dkk., "Redefinisi Unsur "yang Dapat Merugikan Keuangan (Perekonomian) Negara" dalam Tindak Pidana Korupsi," Jurnal Amanna Gappa Volume 25 Nomor 2 (September 2017), h. 14.

\section{7}


subyek hukum pelaku tindak pidana korupsi. Untuk itu adanya kerugian negara menjadi salah satu perhatian dalam penanganan tindak pidana korupsi. ${ }^{13}$

Penegasan dalam rumusan Pasal 27 Ayat (1) bahwa pengelolaan dana pandemi Covid-19 bukan merupakan kerugian negara, juga dipandang sebagai ketentuan yang dapat menegasikan kewenangan Badan Pemeriksa Keuangan (BPK). Sebab, selain berwenang memeriksa pengelolaan dan tanggungjawab keuangan negara, BPK juga berwenang menetapkan jumlah kerugian negara, jika dari hasil pemeriksaan ditemukan berkurangnya uang, surat berharga, dan barang (milik negara). Selain itu, keberadaan pasal tersebut juga dianggap akan mereduksi peran dan fungsi saling control dan saling mengimbangi antar lembaga negara sebagai perwujudan dari penerapan konsep pemisahan kekuasaan (separation of power) dengan prinsip check and balances, yang dimaksudkan untuk menghindari terjadinya abuse of power. ${ }^{14}$

Dari uraian singkat di atas, penulis kemudian tertarik untuk melakukan penelitian, untuk mengetahui bagaimana implikasi dari ketentuan Pasal 27 Ayat (1) Undang-undang Corona, terhadap kewenangan BPK dalam menilai atau menetapkan kerugian Negara.

\section{METODE PENELITIAN}

Penelitian ini menggunakan metode penelitian yuridis normatif, yaitu dengan cara meneliti bahan pustaka atau data sekunder sebagai bahan dasar untuk diteliti. $^{15}$ Pendekatan yang digunakan adalah pendekatan konseptual dan perundang-undangan (conceptual and statute approach). Data dalam penelitian ini diperoleh melalui data sekunder berupa bahan hukum primer, sekunder, dan tertier. Data yang terkumpul kemudian dianalisis dengan menggunakan teknik deskriptif-analitis untuk selanjutnya ditarik kesimpulan.

\section{PEMBAHASAN}

\section{A. Kedudukan Badan Pemeriksa Keuangan Dalam Struktur Ketatanegaraan}

Ide pembentukan Badan Pemeriksa Keuangan (BPK) berasal dari Raad van Rekenkamer pada zaman Hindia Belanda sebagai perpanjangan tangan Gubernur Jenderal dibidang keuangan. Pengaruh Raad van Rekenkamer itu jugalah yang memengaruhi pembentukan lembaga serupa dalam perumusan Undang-undang

13 Bagus Priyo Atmojo, Eksistensi Penentuan Kerugian Negara dalam Penyidikan Tindak Pidana Korupsi, Jurnal Hukum Khaira Ummah, Volume 12 Nomor 4 Desember 2017, h. 700.

14 Jimly Asshiddiqie, Konstitusi dan Konstitualisme Indonesia. (Jakarta: Sekretariat Jenderal dan Kepaniteraan Mahkamah Konstitusi, 2005). h. 58.

15 Seorjono Seokanto dan Sri Mamudji, Penelitian Hukum Normatif (Suatu Tinjauan Singkat), (Jakarta: Rajawali Pers, 2001). h. 13-14. 
Dasar 1945. ${ }^{16}$ BPK sendiri merupakan external auditor terhadap kinerja kuangan Pemerintah, yang telah banyak dipraktikan oleh Negara-negara maju saat sekarang ini, dan diposisikan sebagai salah satu pilar kelembagaan Negara yang penting.

Pengaturan BPK dalam Undang-undang Dasar 1945 (pra perubahan) disatukan dalam BAB VIII tentang Hal Keuangan, sementara pasca perubahan, pengaturannya diatur secara tersendiri dalam BAB VIIA Pasal 23E, Pasal 23F, dan Pasal 23G dengan total 7 ayat. Perubahan dan pengaturan pada BAB tersendiri dalam Undang-undang Dasar Negara Republik Indonesia Tahun 1945 (UUD NRI 1945), menjadi bukti adanya political will untuk memperkuat kelembagaan BPK dalam struktur ketatatanegaraan.

Penguatan terhadap kelembagaan BPK, setidaknya dapat dilihat dalam dua aspek, yaitu aspek struktural dan fungsional. Secara struktural, salah satunya adalah, diamanatkannya pembentukan kantor perwakilan di seluruh provinsi, yang sebelumnya hanya terdapat dibeberapa provinsi. Kemudian dari segi fungsional, Menurut Ni'matul Huda, terdapat tiga perluasan fungsi BPK pasca perubahan UUD NRI 1945, yaitu Pertama, perluasan objek pemeriksaan, yang sebelumnya hanya terhadap pelaksanaan Anggaran dan Pendapatan Belanja Negara (APBN) diperluas mencakup juga Anggaran Pendapatan dan Belanja Daerah (APBD) dan kekuangan dan kekayaan Negara dalam arti luas; Kedua, perluasan terhadap penyampaian hasil pemeriksaan, yang sebelumnya hanya di sampaikan kepada DPR, tetapi sekarang termasuk ke DPD, DPRD Provinsi, dan DPRD Kabupaten/Kota sesuai tingkatan kewenangannya masing-masing; dan Ketiga, perluasan terhadap lembaga yang menjadi objek pemeriksaan, yang sebelumnya hanya terhadap lembaga Negara/pemerintahan yang merupakan subjek Hukum Tata Negara dan Administrasi Negara, meluas dan mencakup organ-organ yang merupakan subjek hukum perdata (BUMN/BUMD) maupun perusahaan swasta yang didalamnya terdapat kekayaan Negara. ${ }^{17}$

Penguatan kelembagaan terhadap BPK, khususnya pasca perubahan UUD NRI 1945, diharapkan berimplikasi terhadap peningkatan kinerja BPK dalam melakukan pemeriksaan terhadap pengelolaan dan tanggungjawab keuangan Negara dalam kapasitasnya sebagai external auditor. Sehingga tata kelola keuangan Negara semakin terbuka, akuntabel, dan bebas dari korupsi, kolusi, dan nepotisme.

\footnotetext{
16 Jimly Asshiddiqie, Perkembangan dan Konsolidasi Lembaga Negara Pasca Reformasi, (Jakarta: Sekretariat Jenderal dan Kepaniteraan Mahkamah Konstitusi, 2006), h. 159.

17 Ni'matul Huda, Hukum Tata Negara Indonesia, (Jakarta: PT. Rajagrafindo Perasada. 2006). h. 208.
} 
Sebagai salah satu lembaga Negara yang nama, bentuk, dan kewenangannya disebutkan langsung UUD NRI 1945. Jimly Asshiddiqie kemudian mengelompokkan BPK sebagai primary constitutional organs, dan disejajarkan dengan kedudukan lembaga-lembaga Negara lainnya, seperti Presiden, DPR, DPD, MPR, Mahkamah Agung, dan Mahkamah Konstitusi. ${ }^{18}$ Dengan demikian, maka secara hierarki dasar hukum pembentukannya, kedudukan BPK dalam struktur ketatanegaraan dapat disebut sebagai lembaga Negara utama (main state organs).

\section{B. Pemisahan Kekuasaan (Separation Of Power) Dan Prinsip Check And Balances}

Salah satu unsur Negara hukum (rechtsstaat) menurut Frederich Julius Stahl, adalah adanya pembagian kekuasaan. Pembagian kekuasaan dimaksudkan sebagai bentuk pembatasan terhadap penggunaan kekuasaan, agar tidak terjadi penumpukan fungsi-fungsi kekuasaan pada satu orang. Kekuasaan yang menumpuk pada satu orang cenderung akan melahirkan kekuasaan yang tiran dan otoriter. ${ }^{19}$

Ide pembagian kekuasaan (distribution of power) juga berkaitan dengan konsep pemisahan kekuasaan (separation of power), yang secara doktrinal, lazimnya merujuk pada konsep Trias Politica dari Baron de Montesquie, yang membagi tiga cabang kekuasaan, yaitu kekuasaan legislatif, kekuasaan eksekutif, dan kekuasaan yudikatif. Moentsquie, mengimpikan pemisahan tiga poros kekuasaan tersebut bersifat mutlak dan tidak saling mencampuri. ${ }^{20}$

Indonesia, khususnya pasca amandemen UUD 1945, pada dasarnya telah menerapkan sistem pemisahan kekuasaan (separation of power), tetapi tidak memberlakukan teori Trias Politica ala Montesquie secara mutlak, karena ketiga poros kekuasaan (legislatif, eksekutif, dan yudikatif) masih memiliki hubungan fungsional dengan menerapkan prinsip check and balances. ${ }^{21}$ Seperti hubungan Presiden dengan DPR dalam menyusun dan menetapkan APBN, hubungan Presiden dengan MA dalam memberikan pertimbangan mengenai pemberian

\footnotetext{
18 Jimly Asshiddiqie, op.cit, h. 111-115.

19 Moh Mahfud MD, Hukum dan Pilar-pilar Demokrasi, (Yogyakarta: Gama Media. 1999),
} h. 23.

20 Jimly Asshiddiqie, Pengantar Hukum Tata Negara Jilid II, (Jakarta: Sekretarial Jenderal dan Kepaniteraan Mahkamah Konstitusi). h. 15.

${ }^{21}$ Menurut Harold Berman sebagaimana dikutip oleh Tahegga Primananda Alfath, Check and balances adalah adalah kontrol konstitusional yang dimana pada setiap pembagian cabang (kekuasaan) pada pemerintahan membatasi kekuasaan satu dengan yang lainnya, jadi tidak ada cabang (kekuasaan) yang dapat menjadi paling tinggi. Lihat. Tahegga Primananda Alfath, "Kedudukan Badan Pemeriksaan Keuangan dalam Sistem Ketatanegaraan Republik Indonesia", Jurnal The Spirit of Law, Volume 1 Nomor 1 Maret 2015, h. 50. 
grasi. Demikian pula hubungan antara DPR dengan BPK dalam hal pemeriksaan dan pengawasan penggunaan keuangan Negara.

Jika menggunakan konsep Trias Politica ala Montesquie, dengan melihat struktur kelembagaan Negara pasca amandemen UUD 1945, maka kekuasaan legislatif dijalankan oleh DPR, DPD, dan MPR. Kekuasaan eksekutif dijalankan oleh Presiden dan Wakil Presiden (dibantu menteri-menteri). Sedangkan kekuasaan kehakiman (yudikatif) dijalankan oleh Mahkamah Konstitusi (MK) dan Mahkamah Agung (MA), sementara Komisi Yudisial bersifat penunjang (auxiliary) terhadap MA dan MK. Pertanyaannya, dimana posisi BPK dalam ketiga cabang kekuasaan di atas, apakah berada dalam rumpun kekuasaan legislatif, eksekutif, atau yudikatif.?

Menurut Jimly Asshiddiqie, kedudukan BPK berada dalam ranah kekuasaan legislatif atau sekurang-kurangnya berhimpitan dengan fungsi pengawasan yang dijalankan oleh Dewan Perwakilan Rakyat (DPR). ${ }^{22}$ Dalam melaksanakan fungsi pengawasan, DPR dan BPK mempunyai hubungan fungsional secara timbal balik yaitu hasil temuan pemeriksaan/pengawasan yang dilakukan oleh BPK merupakan bahan bagi DPR untuk melaksanakan fungsi pengawasan. ${ }^{23}$ Relasi antara BPK dan DPR juga dapat dibaca dalam Pasal 23E Ayat (2) UUD NRI 1945. Adanya kewajiban BPK menyerahkan hasil laporan kepada DPR, DPD, dan DPRD Provinsi dan Kab/Kota semakin memperkuat tesis yang mengelompokkan BPK secara fungsional kedalam ranah legislatif.

Sedangkan hubungan BPK dengan Presiden, adalah berkaitan dengan pertanggungjawaban keuangan Negara, dimana Presiden memegang kuasaan atas pengelolaan keuangan Negara. $^{24}$ Sementara disisi lain, BPK sebagai external auditor, ditugaskan oleh konstitusi untuk melakukan pemeriksaan terhadap pengelolaan dan tanggungjawab keuangan Negara.

Dengan demikian, maka rangkaian pemeriksaan terhadap pengelolaan dan tanggungjawab keuangan negara oleh BPK, termasuk menilai dan menteapkan kerugian negara adalah tugas dan kewenangan konstitusional dalam rangka menjalankan fungsi kontrol dan saling mengimbangi (check and balances) antara lembaga negara untuk meminimalisir terjadinya penyalahgunaan kewenangan dalam pengelolaan keuangan negara, sekaligus untuk memastikan pengelolaan keuangan negara dilakukan sesuai dengan ketentuan peraturan perundangundangan.

\footnotetext{
22 Jimly Asshiddiqie, op.cit, h. 153.

${ }^{23}$ AD. Basniwati, Hubungan DPR dan BPK dalam Melaksanakan Fungsi Pengawasan, Jurnal Hukum Jatiswara, Volume 30 Nomor 1 Oktober 2015, h. 131.

${ }^{24}$ Pasal 6 Ayat (1) Undang-undang Nomor 17 Tahun 2003 tentang Keuangan Negara.
} 


\section{Implikasi Pasal 27 Ayat (1) Undang-Undang Corona Terhadap Kewenangan Bpk Dalam Menetapkan Kerugian Negara}

Pasal 27 Ayat (1) Undang-undang Corona, berbunyi "Biaya yang telah dikeluarkan Pemerintah dan/atau lembaga anggota KSSK dalam rangka pelaksanaan kebijakan pendapatan negara termasuk kebijakan di bidang perpajakan, kebijakan belanja negara termasuk kebijakan di bidang keuangan daerah, kebijakan pembiayaan, kebijakan stabilitas sistem keuangan, dan program pemulihan ekonomi nasional, merupakan bagian dari biaya ekonomi untuk penyelamatan perekonomian dari krisis dan bukan merupakan kerugian Negara".

Keberadaan pasal di atas, dianggap akan menegasikan kewenangan BPK sebagai lembaga yang berwenang memeriksa dan menetapkan kerugian negara, karena ketentuan di atas, secara limitatif mengatur bahwa seluruh biaya yang dikeluarkan oleh Pemerintah dan/atau KSSK hanya merupakan biaya ekonomi dan bukan merupakan kerugian Negara. Sementara, penentuan kerugian dalam pengelolaan keuangan Negara haruslah melalui proses atau mekanisme pemeriksaan (audit), karena jika merujuk pada pengertian kerugian Negara dalam Pasal 1 Ayat (22) Undang-undang Perbendaharaan Negara, maka kerugian Negara harus nyata dan pasti jumlahnya yang diakibatkan oleh perbuatan melawan hukum. ${ }^{25}$

Frasa akibat perbuatan melawan hukum yang terkandung pada norma pasal tersebut, bermakna bahwa tidak semua kondisi dimana berkurangnya uang, surat berharga, dan barang (milik negara) dapat dinyatakan sebagai kerugian negara. Tetapi harus diakibatkan oleh suatu perbuatan melawan hukum. ${ }^{26}$ Sehingga tanpa proses pemeriksaan, tentu akan sulit untuk menentukan apakah kerugian Negara yang terjadi diakibatkan oleh perbuatan melawan hukum atau bukan, termasuk perhitungan mengenai jumlahnya yang harus nyata dan pasti (actual loss).

Pemeriksaan $^{27}$ terhadap pengelolaan dan tanggungjawab keuangan Negara, merupakan amanat konstitusi yang tertuang dalam Pasal 23 E Ayat (1) UUD NRI

25 Pasal 1 Ayat (22) Undang-undang Perbendaharaan Negara, "Kerugian Negara/Daerah adalah kekurangan uang, surat berharga, dan barang, yang nyata dan pasti jumlahnya sebagai akibat perbuatan melawan hukum baik sengaja maupun lalai". Pengertian yang sama juga terdapat dalam Pasal 1 Ayat (15) Undang-undang BPK.

${ }^{26}$ Siti Nurhalimah, "Menyoal Kegentingan dan Pasal Impunitas Perppu Corona," "Adalah" Buletin Hukum \& Keadilan Pusat Studi Konstitusi dan Legislasi Nasional (POSKO-LEGNAS) Fakultas Syariah dan Hukum UIN Syarif Hidayatullah Jakarta Volume 4 Nomor 1 (Tahun 2020), hlm. 42.

27 Pasal 1 Ayat (9) Undang-undang BPK "Pemeriksaan adalah proses identifikasi masalah, analisis, dan evaluasi yang dilakukan secara independen, objektif, dan profesional berdasarkan standar pemeriksaan, untuk menilai kebenaran, kecermatan, kredibilitas, dan keandalan informasi mengenai pengelolaan dan tanggung jawab keuangan negara". 
1945 "Untuk memeriksa pengelolaan dan tanggung jawab tentang keuangan negara diadakan satu Badan Pemeriksa Keuangan yang bebas dan mandiri”. Pasal tersebut, sekaligus menegaskan lembaga yang otoritatif dalam melakukan pemeriksaan, yaitu Badan Pemeriksa Keuangan (BPK), dalam posisinya sebagai external auditor.

Indroharto, pemberian wewenang pemerintahan yang baru oleh suatu ketentuan dalam peraturan perundang-undangan disebut atribusi. ${ }^{28}$ Pendapat yang sama juga diungkapkan oleh Ridwan HR. Menurutnya, kewenangan organ pemerintahan yang diperoleh secara langsung dari redaksi pasal tertentu dalam suatu peraturan perundang-undangan disebut sebagai kewenangan atribusi. ${ }^{29}$ Oleh karena kewenangan BPK dalam melakukan pemeriksaan terhadap pengelolaan keuangan Negara, merupakan kewenangan yang disebut langsung dalam konstitusi, maka dapat dikatakan bahwa kewenangan BPK dalam memeriksa pengelolaan keuangan Negara sebagai kewenangan konstitusional yang bersifat atributif, yang kemudian secara operasional diatur melalui Undang-undang BPK, dan beberapa perundang-undangan lainnya. ${ }^{30}$

Sedangkan kewenangan BPK dalam menilai atau menetapkan kerugian negara dapat dibaca dalam Pasal 10 Ayat (1) Undang-undang BPK, yang berbunyi " $B P K$ menilai dan/atau menetapkan jumlah kerugian negara yang diakibatkan oleh perbuatan melawan hukum baik sengaja maupun lalai yang dilakukan oleh bendahara, pengelola BUMN/BUMD, dan lembaga atau badan lain yang menyelenggarakan pengelolaan keuangan negara."

Nurwahyu Safitri, dkk., bahwa lembaga yang berwenang menetapkan kerugian keuangan negara adalah BPK, karena dalam Pasal 23E, 23F, dan 23G UUD NRI 1945, telah jelas di terangkan bahwa BPK memiliki tugas dan kewenangan atas pemeriksaan pengelolaan keuangan negara sebagai fungsi kontrol dalam pengeluaran pembiayaan oleh pejabat yang berwenang yakni bendahara atau pemegang kekuasaan pada lembaga tersebut. ${ }^{31}$

Kemudian, jika menggunakan pendekatan tiga fungsi BPK, yaitu fungsi operatif, fungsi yudikatif, dan fungsi advisory. ${ }^{32}$ Maka penilaian atau penetapan kerugian Negara merupakan wujud dari fungsi yudikatif, sementara proses

28 Nur Basuki Minarno, Penyalahgunaan Wewenang dan Tindak Pidana Korupsi dalam Pengelolaan Keuangan Negara, (Yogyakarta: Laksbang Mediatama. 2008), h. 70.

29 Ridwan HR, Hukum Administrasi, (Jakarta: Rajawali Pers. 2018), h. 105.

30 Pasal 2 Ayat (2) Undang-undang Nomor 15 Tahun 2004 tentang Pengelolaan dan Tanggung Jawab Keuangan Negara.

${ }^{31}$ Nurwahyu Safitri, dkk. Penetapan Kerugian Keuangan Negara Merupakan Kewenangan BPK atau BPKP, Jurnal Halu Oleo Legal Research, Volume 1 Nomor 2 Agustus 2019, h. 22.

32 Jimly Asshiddiqie, loc. cit, h. 168. 
pemeriksaan merupakan fungsi operatif. Fungsi-fungsi tersebut saling berkaitan antara satu dengan lainnya, dimana fungsi yudikatif merupakan fungsi yang lahir dari hasil pemeriksaan yang merupakan fungsi operatif. Sehingga, meskipun kewenangan menetapkan kerugian Negara tidak disebutkan secara eksplisit dalam konstitusi, tetapi penilaian atau penetapan kerugian Negara merupakan bagian yang berkaitan erat dengan kewenangan pemeriksaan yang dimiliki oleh BPK. Dalam artian, bahwa penilaian atau penetapan kerugian Negara bersifat temuan yang diperoleh dari dari hasil pemeriksaan.

Dari uraian di atas, dapat disimpulkan bahwa, BPK adalah salah satu lembaga Negara yang otoritatif dalam menilai atau menetapkan jumlah kerugian Negara. ${ }^{33}$ Lalu bagaimana implikasi dari dari Pasal 27 Ayat (1) Undang-undang Corona, khususnya frasa “...bukan merupakan kerugian Negara"? Jika ketentuan Pasal 10 Ayat (1) mengenai kewenangan BPK dalam menetapkan kerugian negara, dan Pasal 1 Ayat (15) Undang-undang BPK serta Pasal 1 Ayat (22) Undang-undang Perbendaharaan Negara yang mengatur mengenai kerugian Negara dikaitkan dengan rumusan Pasal 27 Ayat (1) UU Corona, maka jelas terjadi kontradiktif. Ketentuan pertama mengatur mengenai bagaimana dan siapa pihak yang berwenang menyatakan kerugian Negara. Sementara ketentuan yang kedua secara limitatif mengatur bahwa seluruh biaya yang telah dikeluarkan bukan merupakan kerugian Negara.

Untuk menentukan, apakah secara implementatif ketentuan Pasal 27 Ayat (1) Undang-undang Corona, dapat menegasikan kewenangan BPK dalam menilai dan menetapkan kerugian Negara atau tidak, maka dapat digunakan analogi pencabutan perundang-undangan yang diatur dalam Lampiran II Nomor 144 sampai Nomor 147 Undang-undang Nomor 12 Tahun 2012 sebagaimana telah diubah dengan Undang-undang Nomor 15 Tahun 2019 tentang Pembentukan Peraturan Perundang-undangan, yang intinya mengatur bahwa untuk menyatakan ketidakberlakuan atau pencabutan terhadap perundang-undangan, maka harus dimuat secara tegas ketentuan yang dinyatakan tidak berlaku atau dicabut. ${ }^{34}$

${ }^{33}$ Disebut salah satu, karena selain BPK, BPKP juga adalah lembaga yang berwenang menetapkan kerugian Negara, yang kewenangannya telah diperkuat melalui Putusan Mahkamah Konstitusi Nomor 31/PUU-X/2012. Lihat. R. Bayu Fedian, dkk., "Penetapan Kerugian Negara dalam Perkara Tindak Pidana Korupsi" Syiah Kuala Law Journal Volume 2 Nomor 3 (Desember 2018), hlm. 320.

34 Meskipun yang dimaksud dalam Lampiran II Nomor 144 sampai Nomor 147 adalah pencabutan peraturan perundang-undangan, tetapi menurut penulis, susbstansi dari proses pencabutan tersebut juga harusnya diterapkan dalam proses pencabutan pasal-pasal tertentu dalam pelbagai perundang-undangan untuk menghidari terjadinya ketidakpastian hukum. 
Dengan menggunakan analogi di atas, maka untuk dapat menegasikan kewenangan BPK dalam menilai dan menetapkan kerugian negara, maka seharusnya seluruh ketentuan-ketentuan yang mengatur mengenai kewenangan BPK dan kerugian Negara haruslah secara tegas dicabut dan/atau dinyatakan tidak berlaku. Tetapi faktanya, ketentuan-ketentuan yang mengatur mengenai kewenangan BPK maupun kerugian Negara, tidak termasuk bagian dari ketentuan-ketentuan yang secara tegas dicabut dan/atau dinyatakan tidak berlaku dalam Pasal 28 Undang-undang Corona, yang secara khusus memuat dan menegaskan ketidakberlakuan pasal-pasal dari pelbagai Undang-undang. Sementara frasa "bukan merupakan kerugian negara" tidak dapat dijadikan justifikasi, karena rumusannya masih bersifat umum, bahkan cenderung berpotensi menimbulkan disharmonisasi antar peraturan perundangan-undangan. Dengan demikian, maka secara yuridis, keberadaan Pasal 27 Ayat (1) Undangundang Corona, tidak dapat menegasikan kewenangan BPK dalam menetapkan kerugian Negara.

Sehingga, sepanjang dari hasil pemeriksaan pengelolaan dana penanganan pandemi Covid-19, ditemukan berkurangnya uang, surat berharga, dan barang milik Negara yang diakibatkan oleh perbuatan melawan hukum, maka BPK tetap berwenang menetapkan kerugian Negara. Bahkan, jika dalam proses pemeriksaan, BPK menemukan unsur pidana, maka BPK wajib menyampaikan temuan tersebut kepada aparat penegak hukum, sebagaimana ketentuan Pasal 8 Ayat (3) dan Ayat (4) Undang-undang BPK. Ayat (3) "Apabila dalam pemeriksaan ditemukan unsur pidana, BPK melaporkan hal tersebut kepada instansi yang berwenang sesuai dengan ketentuan peraturan perundang - undangan paling lama 1 (satu) bulan sejak diketahui adanya unsur pidana tersebut" Ayat (4) "Laporan BPK sebagaimana dimaksud pada ayat (3) dijadikan dasar penyidikan oleh pejabat penyidik yang berwenang sesuai dengan peraturan perundang-undangan". Ketentuan dengan substansi yang sama juga terdapat dalam Pasal 62 Ayat (2) Undang-undang Perbendaharaan Negara Dan Pasal 14 Undang-undang Pengelolaan dan Tanggungjawab Keuangan Negara.

\section{PENUTUP}

\section{A. Kesimpulan}

Berdasarkan pembahasan diatas maka, disimpulkan sebagai berikut :

1) Ketentuan-ketentuan yang mengatur mengenai kewenangan BPK maupun kerugian Negara, tidak termasuk bagian dari ketentuan-ketentuan yang secara tegas dicabut dan/atau dinyatakan tidak berlaku dalam ketentuan Pasal 28 Undang-undang Corona, yang secara khusus memuat dan menegaskan 
ketidakberlakuan pasal-pasal dari pelbagai Undang-undang. Sementara frasa "bukan merupakan kerugian negara" tidak dapat dijadikan justifikasi, karena rumusannya masih bersifat umum, bahkan cenderung berpotensi menimbulkan disharmonisasi antar peraturan perundangan-undangan. Sehingga secara yuridis, keberadaan Pasal 27 Ayat (1) Undang-undang Corona, tidak dapat menegasikan kewenangan BPK dalam menetapkan kerugian Negara. Kedepan, diharapakan perumusan atau pembentukan Peraturan Pemerintah Pengganti Undang-undang (Perppu) agar tetap memerhatikan dan berpedoman pada asas-asas atau ketentuan-ketentuan yang secara khusus mengatur mengenai pembentukan peraturan perundangundangan, sehingga ketika ditetapkan menjadi Undang-undang, keberadaannya tidak menambah daftar panjang peraturan perundangundangan yang tidak selaras. 


\section{DAFTAR PUSTAKA}

\section{Buku}

Jimly Asshiddiqie. Konstitusi dan Konstitualisme Indonesia. Jakarta: Sekretariat Jenderal dan Kepaniteraan Mahkamah Konstitusi, 2005. Pengantar Hukum Tata Negara Jilid I. Jakarta: Sekretariat Jenderal dan Kepaniteraan Mahkamah Konstitusi. Jakarta, 2006. . Pengantar Hukum Tata Negara Jilid II. Jakarta: Sekretariat Jenderal dan Kepaniteraan Mahkamah Konstitusi, 2006.

Moh. Mahfud MD. Hukum dan Pilar-pilar Demokrasi. Yogyakarta: Gama Media, 1999.

Ni'matul Huda. Hukum Tata Negara Indonesia. Jakarta: PT. Rajagrafindo Perasada. 2006.

Nur Basuki Minarno. Penyalahgunaan Wewenang dan Tindak Pidana Korupsi dalam Pengelolaan Keuangan Daerah. Yogyakarta: Laksbang Mediatama, 2008.

Ridwan HR. Hukum Administrasi Negara. Jakarta: Rajawali Pers, 2018.

Seorjono Seokanto \& Sri Mamudji, Penelitian Hukum Normatif (Suatu Tinjauan Singkat). Jakarta: Rajawali Pers, 2001.

\section{Jurnal dan Prosiding}

AD. Basniwati. Hubungan DPR dan BPK dalam Melaksanakan Fungsi Pengawasan. Jurnal Hukum Jatiswara, Volume 30 Nomor 1 Oktober 2015.

Bagus Priyo Atmojo. Eksistensi Penentuan Kerugian Negara Dalam Penyidikan Tindak Pidana Korupsi. Jurnal Hukum Khaira Ummah, Volume 12 Nomor 4 Desember 2017.

Nurwahyu Safitri, dkk. Penetapan Kerugian Keuangan Negara Merupakan Kewenangan BPK atau BPKP. Jurnal Halu Oleo Legal Research, Volume 1 Nomor 2 Agustus 2019.

R. Bayu Fedian, dkk. Penetapan Kerugian Negara dalam Perkara Tindak Pidana Korupsi. Syiah Kuala Law Journal, Volume 2 Nomor 3 Desember 2018.

Siti Nurhalimah. Menyoal Kegentingan dan Pasal Impunitas Perppu Corona. Buletin Hukum \& Keadilan Pusat Studi Konstitusi dan Legislasi Nasional (POSKO-LEGNAS) Fakultas Syariah dan Hukum UIN Syarif Hidayatullah Jakarta. Volume 4 Nomor 1 Tahun 2020.

Supriyanto, dkk. Redefinisi Unsur "yang Dapat Merugikan Keuangan (Perekonomian) Negara” dalam Tindak Pidana Korupsi. Jurnal Amanna Gappa, Volume 25 Nomor 2 September 2017. 
Tahegga Primananda Alfath. Kedudukan Badan Pemeriksaan Keuangan dalam Sistem Ketatanegaraan Republik Indonesia. Jurnal The Spirit of Law, Volume 1 Nomor 1 Maret 2015.

Website

Direktur Jenderal World Health Organization (WHO), https://www.kompas.com/tren/read/2020/03/12/003124065/menyebarhingga-118-negara-virus-corona-ditetapkan-who-sebagai-pandemi [diakses pada tanggal 20/05/2020].

Humas Mahkamah Konstitusi R.I., "Sejumlah Masyarakat Gugat Konstitusionalitas Perppu corona". https://mkri.id/index.php?page=web.Berita\&id=16330\&menu=2 Diakses tanggal 20/05/2020.

Lembaga Penelitian, Pendidikan, Penerangan Ekonomi Sosial (LP3ES) https://nasional.kompas.com/read/2020/04/06/17522121/lp3es-catat-ada37-pernyataan-blunder-pemerintah-soal-covid-19 Diakses tanggal 20/05/2020.

Sekretariat Kabinet Republik Indonesia, "Isi Perpu Kebijakan Keuangan Negara dan Stabilitas Sistem Keuangan Negara Hadapi Covid-19”. https://setkab.go.id/isi-perpu-kebijakan-keuangan-negara-dan-stabilitassistem-keuangan-hadapi-covid-19/ Diakses tanggal 20/05/2020.

Tirto.id "Update Corona 30 Maret 2020: Data di Indonesia, 31 Provinsi \& Dunia" https://tirto.id/update-corona-30-maret-2020-data-di-indonesia-31provinsi-dunia-eJJx Diakses tanggal 20/05/2020.

\section{Peraturan Perundang-undangan}

Republik Indonesia. Undang-undang Dasar Negara Republik Indonesia Tahun 1945.

Republik Indonesia. Undang-undang RI Nomor 31 Tahun 1999 tentang Pemberantasan Tindak Pidana Korupsi sebagaimana telah diubah dengan Undang-undang Nomor 20 Tahun 2001 tentang Perubahan atas Undangundang Nomor 31 Tahun 1999 tentang Pemberantasan Tindak Pidana Korupsi.

Republik Indonesia. Undang-undang Nomor 17 Tahun 2003 tentang Pengelolaan dan Tanggungjawab Keuangan Negara.

Republik Indonesia. Undang-undang Nomor 1 Tahun 2004 tentang Perbendaharaan Negara.

Republik Indonesia. Undang-undang RI Nomor 15 Tahun 2006 tentang Badan Pemeriksa Keuangan. 
Republik Indonesia. Undang-undang RI Nomor 12 Tahun 2011 tentang Pembentukan Peraturan Perundang-undangan sebagaimana telah diubah dengan Undang-undang Nomor 15 Tahun 2019 tentang Perubahan atas Undang-undang Nomor 12 Tahun 2011 tentang Pembentukan Peraturan Perundang-undangan.

Republik Indonesia. Peraturan Pemerintah Pengganti Undang-undang Nomor 1 Tahun 2020 tentang Kebijakan Keuangan Negara dan Stabilitas Sistem Keuangan untuk Menangani Pandemi Covid-19 dan/atau dalam Rangka Menghadapi Ancaman yang Membahayakan Perekonomian Nasional dan/atau Stabilitas Sistem Keuangan.

Republik Indonesia. Undang-undang RI Nomor 2 Tahun 2020 tentang penetapan peraturan pemerintah pengganti undang-undang nomor 1 tahun 2020 tentang Kebijakan Keuangan Negara dan Stabilitas Sistem Keuangan untuk Penanganan Pandemi Corona Virus Disease 2019 (Covid-19) dan/atau dalam rangka Menghadapi Ancaman yang Membahayakan Perekonomian Nasional dan/atau Stabilitas Sistem Keuangan menjadi Undang-Undang.

Putusan Mahkamah Konstitusi Nomor 26/PUU-XI/2013.

Putusan Mahkamah Konstitusi Nomor 25/PUU-XIV/2016. 